\title{
Exploring the Potential of the Learning Designer as a Teacher Support Tool
}

\author{
Eleni Zalavra ${ }^{1}$ and Kyparisia Papanikolaou ${ }^{2}$ \\ ${ }^{1}$ Athens Directorate of Secondary Education, Athens, Greece \\ ${ }^{2}$ School of Pedagogical and Technological Education, Athens, Greece \\ zalavra@sch.gr \\ kpapanikolaou@aspete.gr \\ DOI: 10.34190/JEL.17.2.04
}

\begin{abstract}
This paper reports on a study carried out with pre-service teachers who first developed a course by designing it in a Learning Design (LD) tool and then implemented it as a course in Moodle. The research explores the potential of the Learning Designer, the LD tool utilized in the study, by addressing three aspects of the LD tool's added value for teachers as designers: a) the development of a learning design, b) the reflection on a design and c) the usefulness of the LD process using an LD tool towards the implementation of a design in a Learning Management System (LMS). The findings suggest that the graphical representation of a learning design provided by the LD tool supports designers to structure learning activities. The components of a learning design incorporated in the LD tool such as the learning outcomes, the type of a learning activity according to a typology and how learners are organized scaffold the articulation of the pedagogy of a learning design. Moreover, the pre-service teachers requested more components e.g. for organizing technology-enhanced learning and more customizable features e.g. for defining and combining activity types. All means of design analysis, especially the graphical ones trigger the designers' reflection on the nature of the activities included in a learning design and provoke them to improve it. The pre-service teachers perceived as beneficial the LD process in the Learning Designer towards considering components of the learning design which are applicable in its implementation as a course in an LMS. Nevertheless, difficulties were reported concerning non-matching and missing components leading to the reconsideration of aspects of the original design during the implementation. The conclusions drawn from the study's findings reveal the potential of the Learning Designer to support teachers as designers and are of value both to researchers involved with developing LD tools and to practitioners interested in harnessing an LD tool to promote LD practices.
\end{abstract}

Keywords: learning design, learning design tools, learning designer, teacher training

\section{Introduction}

In recent years, the importance of teachers being able to design learning tasks and appropriately integrate technology into teaching is internationally recognized (ISTE, 2017). In this line, the field of Learning Design (LD) has received much attention from educational researchers and practitioners recognizing that LD principles and practices greatly influence educational outcomes (Dobozy, 2013). Acknowledging LD as a complex and integrated process, which includes stages of planning, designing, orchestrating and running sequences of teaching and learning activities (Dobozy and Cameron, 2018), LD research investigates the representations, tools, and methodologies that can support educators in the creation of potentially effective LD solutions of diverse types or granularities (Mor, Craft and Hernández-Leo, 2013).

In the area of LD, the LD tools that have been developed provide computer-aided support to the LD process, aiming to make pedagogical decisions explicit and provide computer-interpretable representations of the designs (Prieto, et al., 2014). As noted by Celik and Magoulas (2016), reviewing what has been done regarding teachers' perceptions, practices, and needs of LD tools, there is still limited understanding of teachers' perceptions of these tools and of their design practices while using them. There is also no clear understanding of the reasons behind the lack of adoption among teachers (Mor and Mogilevsky, 2013; Boloudakis, Retalis and Psaromiligkos, 2018) or of the platform features that could mostly appeal to the teacher community (Prieto, et al., 2014). Focusing on teacher training, although it is acknowledged that pre-service and novice teachers should be trained in LD approaches (Persico and Pozzi, 2013), the way LD tools can be incorporated in their training to support the development of a common understanding of LD issues remains a challenging issue (Papanikolaou, Makri and Roussos, 2017).

This paper intends to contribute empirical evidence to the research agenda of the LD tools area, extending work presented by the authors in Zalavra and Papanikolaou (2018). An empirical study was orchestrated so that it leverages an LD tool to support the LD process i.e. planning, implementing, orchestrating and sharing pedagogical ideas, of a course that should be implemented in a Learning Management System (LMS) in a 
teacher education context (Papanikolaou, et al., 2016b). In this paper, we first introduce the Learning Designer the LD tool utilized in the study and the rationale of its selection. Then we describe an empirical study conducted with pre-service teachers aiming to address their perceptions of the added value of the Learning Designer in terms of a) facilitating the development of a learning design, b) supporting the reflection on a design and c) the usefulness of the LD process using the Learning Designer towards the implementation of a design as a course in Moodle. In the last section of the paper, the conclusions drawn from the study's findings are discussed. They reveal the potential of the Learning Designer to support teachers as designers and are of value both to researchers involved in the development of LD tools and to practitioners interested in harnessing an LD tool to promote LD practices.

\section{The Learning Design tool}

\subsection{Selecting the LD tool}

There is a diverse collection of technology-based tools/environments aiming to support the design process and the creation of online repositories to share design examples and practices (Celik and Magoulas, 2016). Indicative examples of LD tools focusing on various aspects of the LD process include the CADMOS (Katsamani and Retalis, 2013), the Cloudworks (Conole and Culver, 2009), the CompendiumLD (Brasher, et al., 2008), the CUVIS (Banerjee and Murthy, 2018), the ILDE (Integrated Learning Design Environment: Hernández-Leo, et al., 2018), the LDTool (Agostinho, 2011), the Learning Designer (Laurillard, et al., 2013; 2018), the PeerLAND (Peer Assessment of LeArNing Designs) (Papanikolaou, et al., 2016a) and the WebCollage (Villasclaras-Fernández, et al., 2013).

Our choice of the Learning Designer as the LD tool for our study was determined by three elements of the particular tool. The first one is its usability due to its simplicity and expressiveness and the fact that it is one of the first available online. The second one is the challenge we felt to explore the rationale of the Learning Designer, as described in Laurillard, et al. (2013), towards supporting teachers as designers to apply effective pedagogy in their learning designs in terms of (a) fostering both individual and social processes and outcomes, (b) promoting the active engagement of the student as learner and (c) converging learning with assessment.

Moreover, we also highly value the features that the tool provides for analyzing certain pedagogical aspects of a learning design such as the types of activities included; which to our knowledge are unique in the panorama of the LD tools available. Since we agree with Ronen-Fuhrmann and Kali (2015) that novice designers have a tendency to jump prematurely to design solutions without deeply exploring the pedagogical rationales behind them, we considered it worthwhile to explore whether the particular LD tool supports designers to deal with this phenomenon. In this line, we intend to investigate how far and in which ways the above features trigger the designers' reflection on their learning designs.

\subsection{The Learning Designer}

The Learning Designer tool is an open-access authoring tool (Laurillard, et al., 2013; 2018), which supports the representation of learning activities. Its design approach aims to scaffold teachers' engagement with LD by employing a pedagogic theory (Laurillard, et al., 2013) based on the Conversational Framework (Laurillard, 2012). The Conversational Framework unifies the main learning theories (didactic, experiential, constructivist and collaborative) in a single representation as cycles of interactions between teacher and learner, and between learner and peers, on both the concept and practice levels of experience (Zhang and Laurillard, 2015). These cycles of interactions that together constitute the complete teaching-learning process are defined as six types of learning (Laurillard, 2012): learning through 1) acquisition (i.e. read/watch/listen), 2) inquiry (i.e. investigation), 3) practice, 4) production, 5) discussion and 6) collaboration. The Conversational Framework is embedded into the Learning Designer by inviting designers to classify each learning activity into one of these six learning types and providing feedback on the resulting balance of the design (Laurillard, et al., 2018).

The tool's interface facilitates teacher-designers to create a design as a sequence of Teaching-Learning Activities (TLAs) while defining the components that they involve i.e. aims, learning outcomes (or objectives), curriculum topics, teaching and learning activities (Laurillard, et al., 2013). Moreover, the tool provides a piechart for each design representing the proportions of the six different learning types that TLAs may include. This analysis of the learning design allows teacher-designers to view designs from various perspectives, e.g. the social dimension of activities, the collaborative dimension of activities, individual practice and the proportion of the time spent on production (Charlton, Magoulas and Laurillard, 2012). The feedback given to teacher- 
designers is, therefore, expected to stimulate them to reflect on and make changes in their designs (Zhang and Laurillard, 2015).

Figure 1 shows an instance of the Learning Designer's interface while developing a learning design on the topic of E-Commerce for a Computer Science course. It provides an insight into how the design approach is actualized in the tool's interface. In area [1] the designer has defined the design's name, topic, learning time, class size and provided a short description. Moreover, the tool has calculated the designed time i.e. the total time defined in the learning activities. In area [2], the designer has filled in the aims of the design and the expected outcomes. S/he has been urged to use Bloom's taxonomy. In area [3], one can see the pie-chart depicting the proportions of activities, based on the relative duration of each of the six different learning types included in the TLAs of this learning design. In area [4] several tools are presented for creating a new design and importing a design as well as exporting it, sharing and saving the current design. The half bottom of the screenshot is occupied by the 2nd, the 3rd and the 4th TLA of the design out of the 5 TLAs designed in total. Focusing, for example, on the structure of the first visible TLA [5], we notice that it consists of 3 elements (a) the description [5.1], (b) the learning activities [5.2] and (c) some notes [5.3]. The representation of each learning activity consists of several components. For instance, the 1st learning activity of this TLA [5.2] is characterised by the designer as a token of the type "read/watch/listen", in other words as aiming at the learners' acquisition [5.2.1], it is has been planned to take 5 minutes and learners participating are supposed to work individually without the presence of a teacher [5.2.2]. Moreover, the designer has attached one learning resource to be used in this activity [5.2.3] and provided a description of the activity [5.2.4]

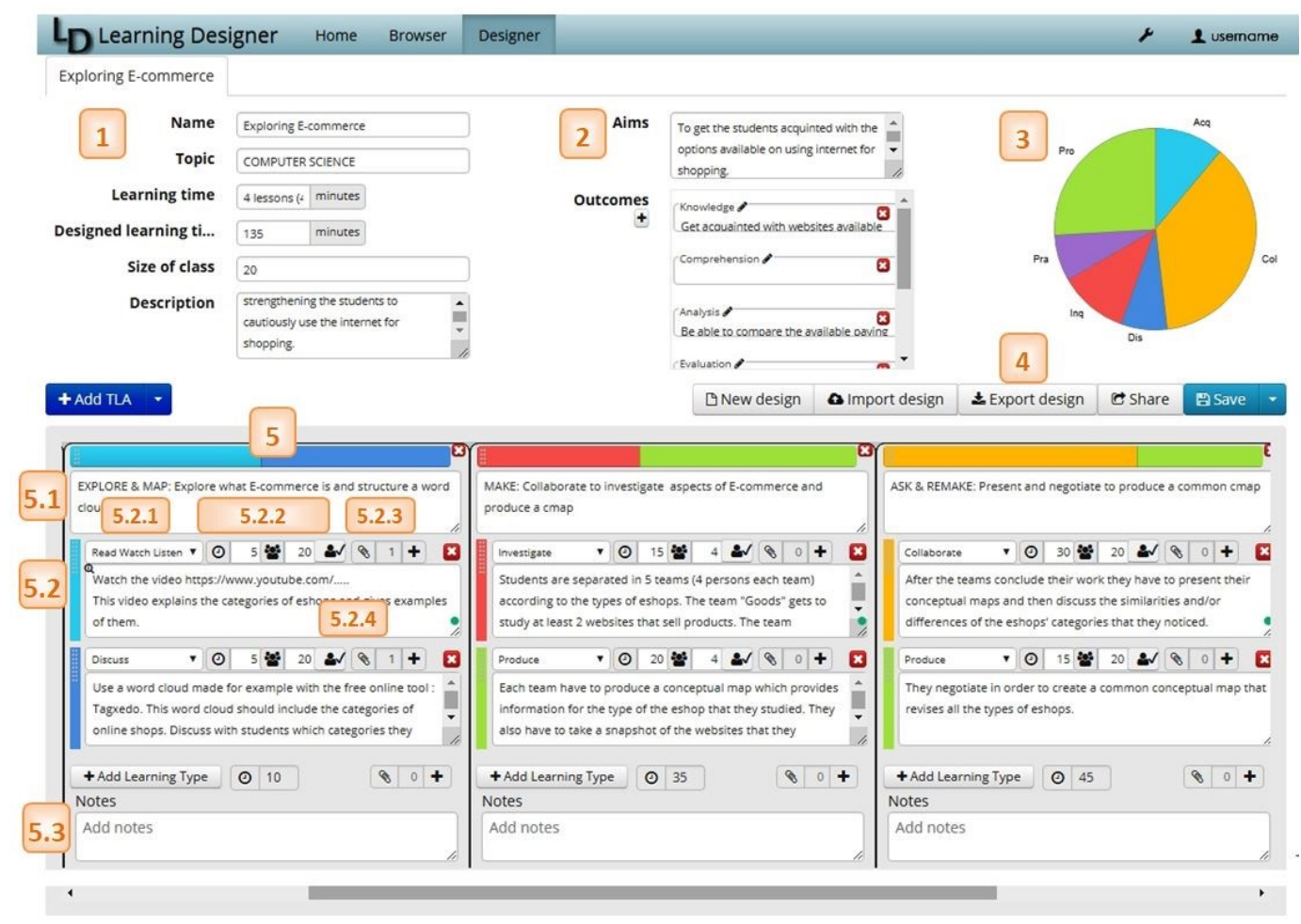

Figure 1: Sample learning design (in edit mode) in Learning Designer

\section{Empirical Study}

\subsection{Methodology}

The study was conducted in the context of a course in Digital Technologies and Distance Learning offered in a postgraduate program on Educational Technology at the National and Kapodistrian University of Athens. The participants were 35 pre-service teachers who attended the course in three consecutive academic years (20142017). Their background was from several disciplines such as Computer Science, Electronics, English or Greek language, Music, Primary Education, etc. During their studies in the postgraduate program, they had developed learning designs in a narrative form. However, none of them had previously used an LD tool for designing a course or an LMS for implementing a learning design. 
During these three academic years, the course was organized in the same way. In the first three weeks, the participants were introduced to the main concepts of distance learning, current trends in web-based learning, adaptive learning environments and educational frameworks that could support the design of educational content for distance or blended learning. Afterward, throughout the following eight weeks, the participants were acquainted with the Learning Designer and Moodle while they were carrying out an LD project as the main course assignment. The LD project was structured in three phases. In the first phase, the participants collaboratively (in groups of two or three) developed a learning design using the Learning Designer based on the following requirements: (a) topic selection from one discipline or ideally interdisciplinary, (b) technology integration into the design, such as web 2.0 tools, (c) adoption of principles for developing distance learning content and (d) support of personalized learning by considering the learners' individual characteristics in developing content. In the second phase, they participated in a peer review activity in order to provide as well as receive peer feedback and redesign their learning designs. In the third phase, they had to implement the learning design as a course in Moodle.

The rationale of asking pre-service teachers to first design using a particular LD tool and then implement the learning design in Moodle derives from the research team's assumption that the design activity entails dealing with ill-defined problems subject to evolving constraints (Mor, Craft and Maina, 2015). We assumed, thus, that a form of guidance through the components of an LD tool and a subsequent reflection on the design would benefit designers; particularly pre-service teachers who are novice designers.

The goal of the research is to explore the potential of the Learning Designer by addressing three aspects of the LD tool's added value for teachers as designers. The research questions were formulated as follows:

RQ1: How do pre-service teachers assess the Learning Designer for facilitating the development of a learning design?

RQ2: How do pre-service teachers value the Learning Designer for promoting reflection on a learning design?

RQ3: How do pre-service teachers perceive the LD process in the Learning Designer towards the implementation of a design in an LMS?

\subsection{Data collection and analysis methods}

Quantitative and qualitative data were collected at the end of the course in a survey questionnaire including 32 questions, of which 25 were Likert-scaled (ranging from 1: Strongly Disagree to 5: Strongly Agree) and 7 were open-ended. To address the three research questions, the questionnaire is divided into three sections.

The 1st section includes 12 Likert-scaled (see Table 1) and 3 open-ended questions (see Table 2) addressing the pre-service teachers' perceptions of the Learning Designer for facilitating the development of a learning design (1st research question). These questions explore how the participants assess the features of the Learning Designer that support the articulation of the design's educational dimension and their expectations of which extra features they would like the tool to have.

The 2 nd section includes 7 Likert-scaled (see Table 4) and 2 open-ended questions (see Table 5) addressing how the pre-service teachers perceive the Learning Designer for promoting reflection on their design (2nd research question). These questions indicate both the feedback provided by and the feedback expected from the tool.

The 3rd section includes 6 Likert-scaled (see Table 6) and 3 open-ended questions (see Table 7) about the participants' perceptions of the usefulness of the Learning Designer as for designing a course to be implemented in an LMS (3rd Research Question). The questions address perceptions of the Learning Designers' usefulness for the development of such a learning design, the positive impact of the initial LD process towards the implementation in Moodle and the difficulties experienced. 


\subsection{Findings}

3.3.1 RQ1: How do pre-service teachers assess the Learning Designer for facilitating the development of a learning design?

The added value of the tool is assessed based on the usefulness perceived by pre-service teachers for articulating a learning design's educational perspective (see Table 1, Q1 to Q12 and Table 2, Q13), the difficulties they faced (see Table 2, Q14) and their expectations from such a tool expressed as a proposal for further development (see Table 2, Q15).

Starting with the tool's usability, the vast majority (88\%) of the participants consider the Learning Designer to be an accessible and easy-to-use tool (Q1). All the participants seem to value the Learning Designer for allowing them to organize a series of teaching and learning activities and establish a clear timetable for the course (Q2). Generally, the participants appreciate the tool's features for defining both individual and collaborative activities in a TLA. Specifically, $74 \%$ of the participants appreciate the Learning Designer for facilitating them to organize learners' work individually or in groups (Q3) and 77\% appreciate the LD tool for fostering the design of collaborative learning activities (Q4) referring to the option of characterizing an activity as individual or collaborative. The way the tool supports the use of Bloom's taxonomy in defining learning outcomes is considered supportive by $83 \%$ of the participants (Q5). The Learning Designer is highly attributed with supporting the design of student-centered learning settings since $86 \%$ of the participants find the predefined types of learning activities proposed as supportive (Q6) while $74 \%$ consider that these types promote learners' active participation (Q7). Nevertheless, responses are equivocal regarding their adequacy since $54 \%$ respond positively, $20 \%$ negatively, while $26 \%$ seems not to have made up their mind yet (Q8). Furthermore, it is worth-reporting that half of the participants respond positively that the LD tool allows for the combination of the types of learning activities, while the other half is divided in negative and neutral responses (Q9). Moreover, 77\% and 66\% of the participants respectively, find the Learning Designer's features supportive in terms of providing resources and designing teaching and learning activities without the teacher's presence that promote autonomous learning (Q10 and Q11). Last, the participants' responses are divided with regard to the potential of the LD tool's predefined types of learning activities to engage the learners in evaluation and self-assessment processes since $43 \%$ respond positively, $40 \%$ negatively and $37 \%$ neutrally (Q12).

Table 1: Distribution of the participants' responses to statements Q1 to Q12 of Section 1 of the survey questionnaire addressing the facilitation of the design process

\begin{tabular}{|c|c|c|c|c|c|}
\hline Statement & 1 & 2 & 3 & 4 & 5 \\
\hline Q1. I consider the Learning Designer to be an accessible and easy-to-use tool. & $\begin{array}{c}0 \\
(0 \%)\end{array}$ & $\begin{array}{c}1 \\
(3 \%)\end{array}$ & $\begin{array}{c}3 \\
(9 \%)\end{array}$ & $\begin{array}{c}13 \\
(37 \%)\end{array}$ & $\begin{array}{c}18 \\
(51 \%)\end{array}$ \\
\hline $\begin{array}{l}\text { Q2. The Learning Designer supports me in organizing a series of teaching and learning } \\
\text { activities and establishing a clear timetable for the course. }\end{array}$ & $\begin{array}{c}0 \\
(0 \%)\end{array}$ & $\begin{array}{c}0 \\
(0 \%)\end{array}$ & $\begin{array}{c}0 \\
(0 \%)\end{array}$ & $\begin{array}{c}12 \\
(34 \%) \\
\end{array}$ & $\begin{array}{c}13 \\
(37 \%)\end{array}$ \\
\hline $\begin{array}{l}\text { Q3. The Learning Designer supports me in organizing on a case-by-case basis alternative } \\
\text { ways of orchestrating learners in the TLA's that I design (working individually or in } \\
\text { teams). }\end{array}$ & $\begin{array}{c}1 \\
(3 \%)\end{array}$ & $\begin{array}{c}1 \\
(3 \%)\end{array}$ & $\begin{array}{c}7 \\
(20 \%)\end{array}$ & $\begin{array}{c}14 \\
(40 \%)\end{array}$ & $\begin{array}{c}12 \\
(34 \%)\end{array}$ \\
\hline Q4. The Learning Designer allows me to design collaborative learning activities. & $\begin{array}{c}0 \\
(0 \%)\end{array}$ & $\begin{array}{c}3 \\
(9 \%)\end{array}$ & $\begin{array}{c}5 \\
(14 \%) \\
\end{array}$ & $\begin{array}{c}16 \\
(46 \%)\end{array}$ & $\begin{array}{c}11 \\
(31 \%)\end{array}$ \\
\hline $\begin{array}{l}\text { Q5. I consider the categorization of the expected outcomes provided by the Learning } \\
\text { Designer adequate for supporting the definition of learning objectives in my learning } \\
\text { design. }\end{array}$ & $\begin{array}{c}0 \\
(0 \%)\end{array}$ & $\begin{array}{c}1 \\
(3 \%)\end{array}$ & $\begin{array}{c}5 \\
(14 \%)\end{array}$ & $\begin{array}{c}16 \\
(46 \%)\end{array}$ & $\begin{array}{c}13 \\
(37 \%)\end{array}$ \\
\hline Q6. The Learning Designer supports me by providing predefined types of learning activities. & $\begin{array}{c}0 \\
(0 \%)\end{array}$ & $\begin{array}{c}1 \\
(3 \%)\end{array}$ & $\begin{array}{c}8 \\
(23 \%)\end{array}$ & $\begin{array}{c}17 \\
(49 \%)\end{array}$ & $\begin{array}{c}9 \\
(26 \%)\end{array}$ \\
\hline $\begin{array}{l}\text { Q7. The Learning Designer provides predefined types of learning activities that promote } \\
\text { learners' active participation }\end{array}$ & $\begin{array}{c}0 \\
(0 \%)\end{array}$ & $\begin{array}{c}2 \\
(6 \%)\end{array}$ & $\begin{array}{c}2 \\
(6 \%)\end{array}$ & $\begin{array}{c}17 \\
(49 \%)\end{array}$ & $\begin{array}{c}13 \\
(37 \%)\end{array}$ \\
\hline $\begin{array}{l}\text { Q8. I consider the predefined types of learning activities provided by the Learning Designer } \\
\text { to be adequate. }\end{array}$ & $\begin{array}{c}2 \\
(6 \%)\end{array}$ & $\begin{array}{c}1 \\
(3 \%)\end{array}$ & $\begin{array}{c}2 \\
(6 \%)\end{array}$ & $\begin{array}{c}19 \\
(54 \%)\end{array}$ & $\begin{array}{c}11 \\
(31 \%)\end{array}$ \\
\hline Q9. The Learning Designer supports me in combining the types of learning activities. & $\begin{array}{c}6 \\
(17 \%)\end{array}$ & $\begin{array}{c}3 \\
(9 \%)\end{array}$ & $\begin{array}{c}9 \\
(26 \%)\end{array}$ & $\begin{array}{c}11 \\
(31 \%)\end{array}$ & $\begin{array}{c}6 \\
(17 \%)\end{array}$ \\
\hline $\begin{array}{l}\text { Q10. The Learning Designer supports me in designing teaching and learning activities that } \\
\text { promote autonomous learning by providing appropriate resources to learners. }\end{array}$ & $\begin{array}{c}2 \\
(6 \%)\end{array}$ & $\begin{array}{c}5 \\
(14 \%)\end{array}$ & $\begin{array}{c}9 \\
(26 \%)\end{array}$ & $\begin{array}{c}14 \\
(40 \%)\end{array}$ & $\begin{array}{c}5 \\
(14 \%)\end{array}$ \\
\hline $\begin{array}{l}\text { Q11. The Learning Designer supports me in designing teaching and learning activities without } \\
\text { the teacher's presence aiming to promote autonomous learning. }\end{array}$ & $\begin{array}{c}1 \\
(3 \%)\end{array}$ & $\begin{array}{c}2 \\
(6 \%)\end{array}$ & $\begin{array}{c}5 \\
(14 \%) \\
\end{array}$ & $\begin{array}{c}18 \\
(51 \%) \\
\end{array}$ & $\begin{array}{c}9 \\
(26 \%) \\
\end{array}$ \\
\hline $\begin{array}{l}\text { Q12. The Learning Designer provides predefined types of learning activities that engage } \\
\text { learners in evaluation and self-assessment processes. }\end{array}$ & $\begin{array}{c}6 \\
(17 \%)\end{array}$ & $\begin{array}{c}8 \\
(23 \%)\end{array}$ & $\begin{array}{c}6 \\
(17 \%)\end{array}$ & $\begin{array}{c}13 \\
(37 \%)\end{array}$ & $\begin{array}{c}2 \\
(6 \%)\end{array}$ \\
\hline
\end{tabular}


As seen in Table 2 regarding Q13, the participants' answers focused on several aspects of the tool that support them in:

- designing the structure and the description of the learning experience planned for the learners (40\%),

- $\quad$ articulating the learning outcomes and the TLAs (31\%),

- designing according to predefined learning activities' types (17\%),

- defining the duration of the TLAs (11\%).

Concerning the participants' responses to Q14, almost half of them report having no difficulties; on the contrary, they think that the tool facilitated the LD process. Having said that, half of the participants feel "limited" by the tool as they would prefer to parameterize it by adding their own learning activities' types or by defining more than one type for each learning activity. Just a few participants mention difficulties related to using the predefined types of activities i.e. they needed support by the tool in order to define the type of each activity and, furthermore, to design particular types of activities such as collaborative or personalized ones. There are also fewer responses reporting the tool's limitation of attaching only web resources to learning activities and the constraint deriving from the visual representation of the TLAs that does not allow long descriptions.

Finally, in Table 2, as far as Q15 is concerned, although 14\% of the participants wouldn't suggest any feature that they would like the LD tool to have, the rest made a considerable number of suggestions, such as:

- providing support in defining/choosing appropriate teaching techniques, technological tools, and resources (26\%),

- $\quad$ allowing the designer to parameterize the learning activities' types and define custom types such as assessment which is not currently included in the predefined ones (17\%),

- $\quad$ supporting synchronous co-authoring of the learning designs (14\%) which indicates the need of designers for synchronous collaborative LD,

- $\quad$ allowing the designer to comment on the learning designs (14\%) thus addressing the need of designers to communicate while collaborating for the development of a learning design,

- providing support for: a) describing the prerequisites of a design (9\%), b) connecting the learning outcomes with the activities that address them (9\%), and c) attaching several types of learning material to the design since the tool supports attaching web resources only (9\%).

Table 2: The participants' responses to the open-ended questions Q13 to Q15 of Section 1 of the survey questionnaire addressing the facilitation of the design process

\begin{tabular}{|c|c|}
\hline Response Category (responses included more than one category) & Frequency \\
\hline \multicolumn{2}{|l|}{ Q13. How far was the Learning Designer useful and in which way(s) was it helpful for developing your learning design? } \\
\hline $\begin{array}{l}\text { Turn ideas into a learning design by scaffolding the structure as well as the description of the learning experience } \\
\text { designed for the learner. }\end{array}$ & $14(40 \%)$ \\
\hline Scaffold clarity while defining the outcomes and describing the TLAs. & $11(31 \%)$ \\
\hline Support at designing TLAs according to suggested/predefined types. & $6(17 \%)$ \\
\hline Support at defining the time assigned for each TLA. & $4(11 \%)$ \\
\hline \multicolumn{2}{|l|}{$\begin{array}{l}\text { Q14. What difficulties did you experience at articulating the educational dimension of your design during the LD process, related to } \\
\text { the Learning Designer? }\end{array}$} \\
\hline I faced no difficulties. I consider it an easy tool that facilitates the LD process. & $15(43 \%)$ \\
\hline I would like to parameterize it (general approach). & $10(29 \%)$ \\
\hline $\begin{array}{l}\text { I would like to parameterize the activities' types. The Learning designer supports only specific learning activities and } \\
\text { doesn't support adding types or being able to characterize an activity as combining } 2 \text { or more types. This is a limitation. }\end{array}$ & $8(23 \%)$ \\
\hline Not being sure how to characterize a learning activity according to the predefined types. & $6(17 \%)$ \\
\hline I would like to attach more types of learning material (not just web sources). & $3(9 \%)$ \\
\hline Long description of learning activities is not visually supported. & $2(6 \%)$ \\
\hline \multicolumn{2}{|l|}{ Q15. What features would you like the Learning Designer to have in order to facilitate the development of a learning design? } \\
\hline $\begin{array}{l}\text { I would like the Learning Designer to support designing for technology-enhanced learning by providing components for } \\
\text { the designer to define/choose teaching techniques and technological tools and resources. }\end{array}$ & $9(26 \%)$ \\
\hline $\begin{array}{l}\text { I would like the Learning Designer to allow teacher-designers to parameterize the activities' types, to allow defining new } \\
\text { and/or allowing to synthesize } 2 \text { predefined types in one activity. }\end{array}$ & $6(17 \%)$ \\
\hline None. & $5(14 \%)$ \\
\hline I would like the Learning Designer to allow synchronous co-editing. & $5(14 \%)$ \\
\hline I would like the Learning Designer to allow commenting on the learning designs. & $5(14 \%)$ \\
\hline I would like the Learning Designer to provide a component for describing the prerequisites of the design. & $3(9 \%)$ \\
\hline I would like the Learning Designer to support the connection of outcomes with the learning activities. & $3(9 \%)$ \\
\hline I would like the Learning Designer to support attaching a variety of learning materials. & $3(9 \%)$ \\
\hline
\end{tabular}


3.3.2 RQ2: How do pre-service teachers value the Learning Designer for promoting reflection on a learning design?

The promotion of reflection is addressed by collecting the pre-service teachers' perceptions of several features of the Learning Designer that are either integrated or should be provided towards promoting their reflection (see Table 3, Q16 to Q22) and requesting their feedback on how far and in which ways the tool stimulated their reflection (see Table 4, Q23 and Q24). The findings suggest that pre-service teachers endorse the Learning Designer for providing means of reflection while authoring a learning design and strongly request more means of analysis as feedback to their designs.

As seen in Table 3, 71\% of the participants consider that the tool stimulates their reflection on the percentage and/or the total time that learners are involved in a collaboration (Q16). Focusing on the analysis of the design in a form of a pie-chart, the overwhelming majority (94\%) do highly value this feedback provided by the tool for analyzing both the time planned for each type of learning activity (Q17) and the learning activities' types incorporated in the design (Q18). Moreover, $86 \%$ of the participants find the information provided by the tool about the duration of the activities planned supportive towards improving the timetable of their learning design while there are no negative responses (Q19). The capacity of the Learning Designer to provide feedback on the proportion of individual to collaborative learning activities included in the learning design is considered useful by $83 \%$ of the participants (Q20). Likewise, the analysis regarding the teacher's presence at the learning activities is appreciated by $75 \%$ of the participants (Q21). Finally, an analysis of the design in terms of the application of technology (Q22) is welcomed by $77 \%$ of the participants.

Table 3: Distribution of the participants' responses to the statements Q16 to Q22 of Section 2 of the survey questionnaire addressing the promotion of reflection

\begin{tabular}{|c|c|c|c|c|c|}
\hline Statement & 1 & 2 & 3 & 4 & 5 \\
\hline $\begin{array}{l}\text { Q16. The Learning Designer supports me in reflecting on the percentage and/or the total } \\
\text { time that learners are involved in a collaboration. }\end{array}$ & $\begin{array}{c}1 \\
(3 \%)\end{array}$ & $\begin{array}{c}3 \\
(9 \%)\end{array}$ & $\begin{array}{c}6 \\
(17 \%) \\
\end{array}$ & $\begin{array}{c}17 \\
(49 \%)\end{array}$ & $\begin{array}{c}8 \\
(23 \%)\end{array}$ \\
\hline $\begin{array}{l}\text { Q17. The Learning Designer supports me in improving my learning design by providing } \\
\text { analysis in the form of a pie-chart as feedback on the design in terms of the time } \\
\text { planned for each type of learning activity. }\end{array}$ & $\begin{array}{c}1 \\
(3 \%)\end{array}$ & $\begin{array}{c}4 \\
(11 \%)\end{array}$ & $\begin{array}{c}7 \\
(20 \%)\end{array}$ & $\begin{array}{c}14 \\
(40 \%)\end{array}$ & $\begin{array}{c}9 \\
(26 \%)\end{array}$ \\
\hline $\begin{array}{l}\text { Q18. The Learning Designer supports me in improving my learning design by providing } \\
\text { analysis in the form of a pie-chart as feedback on the learning activities' types that I } \\
\text { have incorporated in my design. }\end{array}$ & $\begin{array}{c}0 \\
(0 \%)\end{array}$ & $\begin{array}{c}0 \\
(0 \%)\end{array}$ & $\begin{array}{c}2 \\
(6 \%)\end{array}$ & $\begin{array}{c}10 \\
(29 \%)\end{array}$ & $\begin{array}{c}23 \\
(66 \%)\end{array}$ \\
\hline $\begin{array}{l}\text { Q19. The Learning Designer supports me in improving the timetable of my learning design by } \\
\text { informing me through "Learning time" and "Designed time" about the duration of the } \\
\text { activities I have planned. }\end{array}$ & $\begin{array}{c}0 \\
(0 \%)\end{array}$ & $\begin{array}{c}0 \\
(0 \%)\end{array}$ & $\begin{array}{c}5 \\
(14 \%)\end{array}$ & $\begin{array}{c}15 \\
(43 \%)\end{array}$ & $\begin{array}{c}15 \\
(43 \%)\end{array}$ \\
\hline $\begin{array}{l}\text { Q20.I would like the Learning Designer to provide me with an analysis of the design as } \\
\text { feedback for learners' experience working individually or in teams. }\end{array}$ & $\begin{array}{c}0 \\
(0 \%) \\
\end{array}$ & $\begin{array}{c}0 \\
(0 \%)\end{array}$ & $\begin{array}{c}6 \\
(17 \%) \\
\end{array}$ & $\begin{array}{c}17 \\
(49 \%)\end{array}$ & $\begin{array}{c}12 \\
(34 \%)\end{array}$ \\
\hline $\begin{array}{l}\text { Q21.I would like the Learning Designer to provide me with an analysis of the design in terms } \\
\text { of teacher presence/non-presence. }\end{array}$ & $\begin{array}{c}0 \\
(0 \%) \\
\end{array}$ & $\begin{array}{c}0 \\
(0 \%) \\
\end{array}$ & $\begin{array}{c}2 \\
(6 \%)\end{array}$ & $\begin{array}{c}11 \\
(31 \%)\end{array}$ & $\begin{array}{c}22 \\
(63 \%) \\
\end{array}$ \\
\hline $\begin{array}{l}\text { Q22.I would like the Learning Designer to provide me with an analysis as feedback on the } \\
\text { design in terms of the application of technology in the design. }\end{array}$ & $\begin{array}{c}0 \\
(0 \%)\end{array}$ & $\begin{array}{c}0 \\
(0 \%)\end{array}$ & $\begin{array}{c}8 \\
(23 \%)\end{array}$ & $\begin{array}{c}13 \\
(37 \%)\end{array}$ & $\begin{array}{c}14 \\
(40 \%)\end{array}$ \\
\hline
\end{tabular}

As seen in Table 4 regarding Q23, the responses highlight two aspects of the tool. The first one concerns the feature of the pie chart which is deemed as really useful for a considerable percentage of the respondents (69\%) since it allows them to realize what types of activities they have designed and stimulates them to include as many types of activities as possible. The other one addresses the potential to realize the time distribution of the TLAs in order to produce a well-balanced pie-chart including different types of activities (80\%). There are also fewer responses (14\%) indicating that the visual analysis of the pie-chart prompted them to focus on specific types of activities such as collaboration and practice. Regarding Q24, the pie-chart is described as depicting either the time distribution of various types of activities or the type of the activities included in the design, thereby enhancing the participants' reflection on what they have actually designed and inspiring corrections. There are also fewer participants who expressed their appreciation for the visualization provided by the tool, compared to their previous experience of designing in a narrative form. Last, there are also a few positive comments on the feedback provided for the calculation of the total time of the design. 
Table 4: The participants' responses to the open-ended questions Q23 and Q24 of Section 2 of the survey questionnaire addressing the promotion of reflection.

\begin{tabular}{|c|c|}
\hline Response Category (responses included more than one category) & Frequency \\
\hline \multicolumn{2}{|c|}{$\begin{array}{l}\text { Q23. How did the analysis of the design through the pie-chart stimulate your reflection? In which way did it evoke the revision of your } \\
\text { learning design? }\end{array}$} \\
\hline I tried to produce a pie-chart that includes as many different types of activities as possible. & $24(69 \%)$ \\
\hline $\begin{array}{l}\text { I tried to produce a well-balanced pie-chart so that I design an equal distribution of different types of activities } f \mathrm{c} \\
\text { learners. }\end{array}$ & $28(80 \%)$ \\
\hline $\begin{array}{l}\text { I revised the original design so as to reduce activities of learning through acquisition and include more TLAs of } \\
\text { collaboration and practice. }\end{array}$ & $5(14 \%)$ \\
\hline \multicolumn{2}{|l|}{$\begin{array}{l}\text { Q24. How far was the Learning Designer useful for your reflection and in which way(s) was it helpful for providing feedback during } \\
\text { the LD process? }\end{array}$} \\
\hline $\begin{array}{l}\text { The pie-chart provides analysis of the types of the activities included in the learning design thus allowing for the } \\
\text { designer's reflection and correction in case the distribution of the types of activities are not adequate for the learning } \\
\text { experience planned. }\end{array}$ & $16(46 \%)$ \\
\hline $\begin{array}{l}\text { The pie-chart provides analysis of the time spent for each type of activity included in the learning design thus allowing } \\
\text { for the designer's reflection and correction in case the time distribution of activities is not adequate for the learning } \\
\text { experience planned. }\end{array}$ & $10(29 \%)$ \\
\hline Visualization during the LD process allows "realizing" what is actually designed. & $6(17 \%)$ \\
\hline Feedback given to the designer by calculating the total time of the activ & $3(9 \%)$ \\
\hline
\end{tabular}

3.3.3 RQ3: How do pre-service teachers perceive the $L D$ process in the Learning Designer towards the implementation of a design in an LMS?

Table 5 includes the pre-service teachers' responses to statements addressing their perceptions regarding the usefulness of the LD process supported by the Learning Designer towards the implementation of a design in an LMS. The majority (86\%) of the participants perceive that the Learning Designer has features that foster teacher-designers during the LD process (Q25) and 72\% consider that the LD process actualized at the tool contributes to developing new ideas and realizing important elements of their teaching practice (Q26). Designing in the LD tool is considered beneficial towards implementing their learning design in the LMS by $80 \%$ of the participants (Q27). The participants gave mixed responses about accessing learning designs shared in the Learning Designer while they are developing their own learning design, with $34 \%$ responding positively, $55 \%$ negatively and $11 \%$ being neutral (Q28). Actually, they hadn't used this feature during the course. However, $89 \%$ reported that they consider the tool's option for sharing the learning designs beneficial for sharing their ideas and transforming their teaching practice (Q29). Assuming their future role as in-service teachers, $60 \%$ stated that they intended to use the tool for developing their learning designs in the future (Q30) which is really important.

Table 5: Distribution of the participants' responses to statements Q25 to Q30 of Section 3 of the survey questionnaire addressing the usefulness of the Learning Designer for designing a course to be implemented in an LMS.

\begin{tabular}{|c|c|c|c|c|c|}
\hline Statement & 1 & 2 & 3 & 4 & 5 \\
\hline Q25. The Learning Designer's features foster me during the LD process. & $\begin{array}{c}0 \\
(0 \%)\end{array}$ & $\begin{array}{c}1 \\
(3 \%)\end{array}$ & $\begin{array}{c}4 \\
(11 \%)\end{array}$ & $\begin{array}{c}13 \\
(37 \%)\end{array}$ & $\begin{array}{c}17 \\
(49 \%)\end{array}$ \\
\hline $\begin{array}{l}\text { Q26. Through the LD process at the Learning Designer, I developed new ideas and realized } \\
\text { important elements of my teaching practice. }\end{array}$ & $\begin{array}{c}0 \\
(0 \%)\end{array}$ & $\begin{array}{c}2 \\
(6 \%)\end{array}$ & $\begin{array}{c}8 \\
(23 \%)\end{array}$ & $\begin{array}{c}17 \\
(49 \%)\end{array}$ & $\begin{array}{c}8 \\
(23 \%) \\
\end{array}$ \\
\hline $\begin{array}{l}\text { Q27. I consider designing in the Learning Designer significantly helpful towards } \\
\text { implementing my learning design in the LMS. }\end{array}$ & $\begin{array}{c}0 \\
(0 \%)\end{array}$ & $\begin{array}{c}1 \\
(3 \%)\end{array}$ & $\begin{array}{c}6 \\
(17 \%) \\
\end{array}$ & $\begin{array}{c}13 \\
(37 \%)\end{array}$ & $\begin{array}{c}15 \\
(43 \%)\end{array}$ \\
\hline $\begin{array}{l}\text { Q28. While developing my learning design I looked at and took into consideration the } \\
\text { learning designs shared at the Learning Designer. }\end{array}$ & $\begin{array}{c}9 \\
(26 \%)\end{array}$ & $\begin{array}{c}10 \\
(29 \%)\end{array}$ & $\begin{array}{c}4 \\
(11 \%)\end{array}$ & $\begin{array}{c}7 \\
(20 \%)\end{array}$ & $\begin{array}{c}5 \\
(14 \%)\end{array}$ \\
\hline $\begin{array}{l}\text { Q29. I consider sharing learning designs in the Learning Designer significantly beneficial } \\
\text { towards teachers' sharing their ideas and transforming their teaching practice. }\end{array}$ & $\begin{array}{c}0 \\
(0 \%)\end{array}$ & $\begin{array}{c}2 \\
(6 \%)\end{array}$ & $\begin{array}{c}2 \\
(6 \%)\end{array}$ & $\begin{array}{c}15 \\
(43 \%)\end{array}$ & $\begin{array}{c}16 \\
(46 \%)\end{array}$ \\
\hline Q30.I intend to use the Learning Designer for developing my learning designs. & $\begin{array}{c}1 \\
(3 \%)\end{array}$ & $\begin{array}{c}3 \\
(9 \%)\end{array}$ & $\begin{array}{c}10 \\
(29 \%)\end{array}$ & $\begin{array}{c}18 \\
(51 \%)\end{array}$ & $\begin{array}{c}3 \\
(9 \%)\end{array}$ \\
\hline
\end{tabular}


Table 6 includes a categorization of the participants' responses to the open-ended questions Q31 and Q32. Regarding Q31, the participants note that the Learning Designer facilitated them as designers to:

- turn their ideas into a structure that could be utilized in the implementation of their design in Moodle (66\%),

- realize the proportion of learning activities included in their learning design and adjust it in their implementation (20\%),

- become aware of the several components of their design that are either applicable in the implementation (11\%) or non-applicable but essential toward planning the learning setting (14\%),

- realize the time distribution of the design in order to adjust it at the implementation in Moodle (11\%).

An insightful response given by a participant was: "The structure and the components provided by the Learning Designer, in relation to the lack of such support by the LMS, were quite helpful. I think that if I had to develop the learning design in the LMS without having designed it first in the Learning Designer, I would be "lost" and have not realized what I had actually been designing. Moreover, I wouldn't have thought of including information such as the learning outcomes or the time distribution of each task."

Regarding Q32, 34\% of the participants report no difficulties while developing the Moodle course and admit to the fact that they were consulting their learning design in the Learning Designer. The rest of the responses mention:

- facing difficulties in matching the components of the learning design represented in the LD tool with adequate tools to be implemented by the LMS (34\%),

- constraints in finding appropriate tools provided by the LMS which forced them to redesign the initial orchestration of the learning activities in the LD tool (26\%).

Table 6: The participants' responses to the open-ended questions Q31 and Q32 of Section 3 of the survey questionnaire addressing the usefulness of the Learning Designer for designing a course to be implemented in an LMS

\begin{tabular}{|l|l|}
\hline $\begin{array}{l}\text { Response Category (responses included more than one category) } \\
\text { Q31. How was the initial LD process in the Learning Designer helpful towards the implementation of your learning design as a course } \\
\text { in Moodle? }\end{array}$ & Frequency \\
\hline $\begin{array}{l}\text { The tool supported me in turning my ideas into a structure which was also applicable in Moodle. } \\
\text { Realizing what learning activities are incorporated in the design and adjusting its distribution in order to include a variety } \\
\text { of activity types in the implementation in Moodle. }\end{array}$ & 7 (20\%) \\
\hline $\begin{array}{l}\text { Considering components of the design that although not applicable in the implementation, were essential toward } \\
\text { planning the students' learning experience (e.g. defining outcomes matching the learning activities). }\end{array}$ & 5 (14\%) \\
\hline $\begin{array}{l}\text { Considering components of the design that were also applicable in the implementation (e.g. resources to be given as } \\
\text { learning material). }\end{array}$ & 4 (11\%) \\
\hline Realizing the time distribution of the learning activities in order to adjust it at the implementation in Moodle. & 4 (11\%) \\
\hline $\begin{array}{l}\text { Q32. How did the initial LD process in the Learning Designer make it difficult to implement your learning design as a course in } \\
\text { Moodle? }\end{array}$ & 12 (34\%) \\
\hline No difficulties. & 12 (34\%) \\
\hline I had to match the learning activity designed at the Learning Designer with tools provided by Moodle. \\
\hline $\begin{array}{l}\text { I had to change the initial orchestration of the learning activities at the Learning Designer in order to adjust my rationale } \\
\text { to the tools provided by Moodle. }\end{array}$ & 9 (26\%) \\
\hline
\end{tabular}

\section{Discussion and conclusions}

This paper reports on a study of pre-service teachers' initial experience with developing a course in an LMS after they had first designed it in an LD tool. The research explores the potential of the Learning Designer, the LD tool utilized in the study, by addressing three aspects of an LD tool's added value for teachers as designers concerning: a) the development of a learning design, b) the reflection on the design and c) the usefulness of the LD process using the Learning Designer towards the implementation of the design in Moodle.

With regard to facilitating teacher-designers to develop a learning design, the findings suggest that the Learning Designer has such features. The participants endorsed the TLA representation provided by the tool and its integrated components for orchestrating the classroom. In their majority, they also seemed to acknowledge this graphical approach for the design representation as quite supportive towards structuring a learning design, providing evidence in favor of graphical vs textual representation of a design to the LD research field (Dagnino, et al., 2018). Features of the learning activities' representation that are also appreciated include duration, quantitative data defining the number of learners participating individually or in each group, the teacher's presence in relation to learner autonomy and attaching resources. These 
pedagogical characteristics of a learning design that need to be defined by a designer are considered to scaffold the LD process. In the case of the Learning Designer, the component for defining the expected outcomes by describing them as well as categorizing them according to Bloom's taxonomy was highly valued. The feature of choosing among six predefined learning activities according to the activity typology proposed by Laurillard (2012) in the Conversational Framework was considered helpful, although participants propose that such features be customizable and extendable to include other types of activities such as evaluation and selfassessment. This finding validates the issue raised by Boloudakis, Retalis and Psaromiligkos (2018) about the prerequisite of an LD tool to provide flexibility to designers in terms of being theory and context independent.

In this line, the wish list of the participants, including what they would like the Learning Designer to provide so that it facilitates them during the LD process, is quite interesting. The request for support at micro-level to the selection of teaching techniques, technological tools and resources, reveals the high demand of teacherdesigners to be supported for integrating technology in their designs i.e. designing technology-enhanced learning. In accordance with the literature reporting the need to support the cooperation among teacherdesigners (Dagnino, et al., 2018) and Laurillard, et al. (2018) acknowledging that the Learning Designer needs to provide designers with the capacity to collaborate on developing designs, the pre-service teachers in this study request that the tool supports collaborative LD by providing synchronous co-authoring of the learning designs and commenting capabilities.

With regard to promoting teacher-designers to reflect on their design, highly valued are all means of a design's analysis that enhance the designers' reflection on the nature of the activities included in a learning design. The pre-service teachers valued the calculation of the designed time for assisting the establishment of a clear timetable for the learning activities planned. The findings reveal that the graphical feedback in the form of a pie chart included in the Learning Designer triggered the pre-service teachers' reflection and provoked the improvement of their designs in two directions, either towards including as many types of activities as possible or towards focusing on specific types of activities. The apparent preference for the reflection value of LD tools (Prieto, et al., 2014) is validated by the participants requesting more means of analysis such as the promotion of autonomous learning and the application of technology.

The research team's assumption that a form of guidance through the components of an LD tool and a subjacent reflection on the design would benefit designers -particularly novice designers- is validated. Designing in the Learning Designer prior to implementing the learning design as a course in Moodle was regarded as beneficial towards considering components of the learning design that are applicable in the implementation. Nevertheless, the fact that components of the learning design represented in a specific LD tool may not match the elements available in an LMS is an issue that provokes designers to reconsider aspects of their design during the implementation phase. Consequently, this study highlights the need to consider the development of an LD tool's features in conjunction with those of an LMS' and is in line with the study of Laurillard, et al. (2018) anticipating that the Learning Designer supports integration with Virtual Learning Environments.

We conclude that an LD tool like the Learning Designer has the potential to support teacher-designers in developing a learning design. The participants' perceptions of their experience in the context of the study are valuable to the research agenda of the LD tools underlining features of an LD tool that appeal and are beneficial to teacher-designers as well as proposed extensions. Moreover, the organization of the study and its implications could be considered by practitioners interested in harnessing an LD tool to promote their LD practices before developing it in an LMS.

\section{References}

Agostinho, S., 2011. The use of a visual learning design representation to support the design process of teaching in higher education. Australasian Journal of Educational Technology, 27(6).

Banerjee, G. and Murthy, S., 2018. CuVIS: An interactive tool for instructors to create effective customized learning designs with visualizations. Australasian Journal of Educational Technology, 34(2).

Brasher, A., Conole, G., Cross, S., Weller, M., Clark, P. and White, J., 2008. CompendiumLD-a tool for effective, efficient and creative learning design. In: Proceedings of the 2008 European LAMS Conference: Practical Benefits of Learning Design, 25-27 June 2008, Cadiz, Spain.

Boloudakis, M., Retalis, S. and Psaromiligkos, Y., 2018. Training Novice teachers to design moodle-based units of learning using a CADMOS-enabled learning design sprint. British Journal of Educational Technology, 49(6), pp.1059-1076. 
Charlton, P., Magoulas, G. and Laurillard, D., 2012. Enabling creative learning design through semantic technologies. Technology, Pedagogy and Education, 21(2), pp.231-253.

Celik, D. and Magoulas, G., 2016. Teachers' perspectives on design for learning using computer based information systems: A Systematic Literature Review. In Conference Proceedings-UKAIS; University of Oxford.

Conole, G. and Culver, J., 2009. Cloudworks: Social networking for learning design. Australasian Journal of Educational Technology, 25(5), pp.763-782.

Dagnino, F.M., Dimitriadis, Y.A., Pozzi, F., Asensio-Pérez, J.I. and Rubia-Avi, B., 2018. Exploring teachers' needs and the existing barriers to the adoption of Learning Design methods and tools: A literature survey. British Journal of Educational Technology, 49(6), pp.998-1013.

Dobozy, E., 2013. Learning design research: advancing pedagogies in the digital age. Educational Media International, 50(1), pp.63-76.

Dobozy, E. and Cameron, L., 2018. Special issue on learning design research: Mapping the terrain. Australasian Journal of Educational Technology, 34(2).

Hernández Leo, D., Asensio-Pérez, J.I., Derntl, M., Pozzi, F., Chacón Pérez, J., Prieto, L.P. and Persico, D., 2018. An integrated environment for learning design. Frontiers in ICT. 2018; 5: 9.

International Society for Technology and Education, 2017. ISTE standards for Educators. Retrieved 01 March 2019, from https://www.iste.org/standards/for-educators .

Katsamani, M. and Retalis, S., 2013. Orchestrating learning activities using the CADMOS learning design tool. Research in Learning Technology, 21.

Laurillard, D., 2013. Teaching as a design science: Building pedagogical patterns for learning and technology. Routledge.

Laurillard, D., Charlton, P., Craft, B., Dimakopoulos, D., Ljubojevic, D., Magoulas, G., Masterman, E., Pujadas, R., Whitley, E.A. and Whittlestone, K., 2013. A constructionist learning environment for teachers to model learning designs. Journal of Computer Assisted Learning, 29(1), pp.15-30.

Laurillard, D., Kennedy, E., Charlton, P., Wild, J. and Dimakopoulos, D., 2018. Using technology to develop teachers as designers of TEL: Evaluating the learning designer. British Journal of Educational Technology, 49(6), pp.1044-1058.

Mor, Y., Craft, B. and Hernández-Leo, D., 2013. Editorial: The art and science of learning design, Research in Learning Technology, 210. doi: 10.3402/rlt.v21i0.22513.

Mor, Y., Craft, B. and Maina, M., 2015. Introduction: Learning design: Definitions, current issues and grand challenges. The art and science of learning design. SensePublishers, Rotterdam.

Mor, Y. and Mogilevsky, O., 2013. The learning design studio: collaborative design inquiry as teachers' professional development. Research in Learning Technology, 21.

Papanikolaou, K.A., Gouli, E., Makrh, K., Sofos, I. and Tzelepi, M., 2016a. A peer evaluation tool of learning designs. In European Conference on Technology Enhanced Learning (pp. 193-206). Springer, Cham.

Papanikolaou, K.A., Makrh, K., Magoulas, G.D., Chinou, D., Georgalas, A. and Roussos, P., 2016b. Synthesizing technological and pedagogical knowledge in learning design: a case study in teacher training on technology enhanced learning. International Journal of Digital Literacy and Digital Competence (IJDLDC), 7(1), pp.19-32.

Papanikolaou, K., Makri, K. and Roussos, P., 2017. Learning design as a vehicle for developing TPACK in blended teacher training on technology enhanced learning. International Journal of Educational Technology in Higher Education, 14(1), p.34.

Persico, D. and Pozzi, F., 2013. The role of representations for the development of a participatory culture of Learning Design among educators. Parmigiani D, Pennazio AY V (eds) Learn Teach Media Technol. AISBL Brussels, Belgium, pp.365-372.

Prieto, L.P., Tchounikine, P., Asensio-Pérez, J.I., Sobreira, P. and Dimitriadis, Y., 2014. Exploring teachers' perceptions on different CSCL script editing tools. Computers \& Education, 78, pp.383-396.

Ronen-Fuhrmann, T. and Kali, Y., 2015. Concretization of design ideas in the context of educational technology design. In The art \& science of learning design (pp. 31-47). SensePublishers, Rotterdam.

Villasclaras-Fernández, E., Hernández-Leo, D., Asensio-Pérez, J. I. and Dimitriadis, Y., 2013. Web Collage: An implementation of support for assessment design in CSCL macro-scripts. Computers \& Education, 67, pp.79-97.

Zalavra, E. and Papanikolaou, K., 2018. Supporting the Learning Design Process: Insights Into Pre-Service Teachers' Perceptions. In European Conference on e-Learning (pp. 620-629). Academic Conferences International Limited.

Zhang, Y. and Laurillard, D., 2015. Planning and sharing learning designs: cross-cultural use of a learning design support tool. Learning: Research and Practice, 1(2), pp.152-161. 